\title{
Morphology and development of leaf papillae in the Pilotrichaceae ${ }^{1}$
}

\author{
Ana Gabriela Duarte-Silva ${ }^{2,3}$, Micheline Carvalho-Silva ${ }^{2}$ and Paulo Eduardo Aguiar Saraiva Câmara ${ }^{2}$
}

Submitted: 7 January, 2013. Accepted: 22 July, 2013

\begin{abstract}
Sporophyte morphology has been traditionally used in taxonomic studies of pleurocarpous mosses. However, the gametophyte morphology of the Pilotrichaceae still holds interesting and under-investigated characters. Here, we conducted an in-depth investigation of the morphology and development of Pilotrichaceae leaf papillae and assessed their usefulness in inferring the evolutionary history of the family. Specimens were observed under scanning electron microscopy, and we identified seven morphological types of papillae, as well as two different pathways of development. Our results suggest that papilla morphology and development are phylogenetically informative in the Pilotrichaceae.
\end{abstract}

Key words: Gametophyte, Hookeriales, pleurocarpous moss, outgrowths, scanning electron microscopy

\section{Introduction}

The Pilotrichaceae is the most diverse family within the Hookeriales, comprising 21 genera and approximately 420 species worldwide (Goffinet et al. 2009; Crosby et al. 2000). The family is distributed throughout the tropics but is particularly diverse in the neotropics, whereas there are approximately 200 species, representing all 21 genera, of which 15 are endemic (Gradstein et al. 2001).

Variation in sporophytic traits is central to most taxonomic concepts within the Pilotrichaceae (Brotherus 1925; Crosby 1974; Crum 1984; Buck \& Goffinet 2000). Phylogenetic inferences (Buck et al. 2005), however, suggest that several genera, as circumscribed today, are polyphyletic: Brymela Crosby \& B.H. Allen, Hypnella (Müll. Hal.) A. Jaeger; Lepidopilidium (Müll. Hal.) Broth.; Lepidopilum (Brid.) Brid.; Stenodictyon A. Jaeger ex M. Fleisch.; and Trachyxiphium W.R. Buck. The polyphyletic nature of those genera suggests that their diagnostic traits are homoplasious.

Sporophyte morphology has traditionally been used to delimitate certain taxa among the pleurocarpous mosses (Hedenäs 1996; Buck 1998; Buck et al. 2005), as observed in the Sematophyllaceae genera Paranapiacabaea W.R. Buck \& D.M. Vital and Donnellia Austin, as well as in the Pilotrichaceae genera Lepidopilum (Brid.) Brid. and Lepidopilidium (Müll Hal.) Broth. However, sporophytes are highly susceptible to environmental alterations (Hedenäs 2007) and may not be as highly conserved as are gametophytes (Câmara \& Buck 2012). In some groups, gametophyte morphology has been found to show better congruence with molecular data (Gardiner et al. 2005; Hedenäs 2007;
Câmara \& Kellogg 2010) and gametophyte morphology of pleurocarpous mosses remains a promising source of taxonomically distinctive features, such as leaf morphology (Buck 2007; Câmara \& Kellogg 2010).

Papillae and mammillae are cell ornamentations present in many mosses. These protuberances are distinguished by their nature (Magill 1990): solid cell wall thickening (papillae) versus hollow projections without wall thickening (mammillae). The shape, location, development and number of papillae per cell are not easily visualized under light microscopy and may in fact often be misinterpreted as the C-shaped papillae observed in Syntrichia ruralis (Hedw.) F. Weber \& D. Mohr, which reflects optical distortions in light microscopy (Robinson 1971; Cano 1994). Within the Pilotrichaceae, light microscopy reveals mostly whether papillae are present or absent, a trait used in distinguishing among various genera and species (Buck 1998; Vaz-Imbassahy et al.2008). Other features such as shape, size and precise location of the papillae are virtually impossible to assess under light microscopy, and, to our knowledge, there have been no scanning electron microscopy (SEM) studies characterizing papillae diversity in the Pilotrichaceae.

Leaf papilla morphology in pleurocarpous mosses has been investigated under SEM only in the Sematophyllaceae (Câmara \& Kellogg 2010). In acrocarpous mosses, such studies are more common, for example, in the Fissidentaceae (Belin et al. 1974) and Polytrichaceae (Atrichum P. Beauv. by Ireland (1991) and Pottiaceae (Werner et al. 2003). In such studies, SEM has revealed important taxonomic features, such as papillae shape, size and origin. Current observations of papillae within Pilotrichaceae are mostly

\footnotetext{
${ }^{1}$ Based on the Master's dissertation of the first author

${ }^{2}$ Universidade de Brasília, Campus Universitário Darcy Ribeiro, Instituto de Ciências Biológicas, Departamento de Botânica, Brasília, DF, Brazil

${ }^{3}$ Author for correspondence: anagabriela_bio@yahoo.com.br
} 
restricted to presence or absence, number per cell (unipapillose or pluripapillose) and location on the leaf (apex or base). In the present study, we use SEM to investigate further papillae development and morphology across genera in Pilotrichaceae and a published phylogeny (Buck et al. 2005) to determine the possibility of using it to infer the evolutionary history of the family.

\section{Material and methods}

\section{Taxon sampling}

We sampled at least two species of every papillose genus of the Pilotrichaceae. For Hypnella diversifolia (Mitt.) A. Jaeger, three specimens were sampled because the material is readily accessible in herbaria in Brazil. Two species of Cyclodictyon Mitt. (a non-papillose genus) were chosen at random among those studied by Buck et al. (2005) as a control to confirm papilla absence under SEM. We also investigated Hypnella pilifera (Hook. f. \& Wilson) A. Jaeger, although it was not sampled in Buck et al. (2005), because it is a very common species with strongly papillose laminar cells. Overall, we studied the following species and specimens: Callicostella colombica R. S. Williams (Colombia, Churchill et al.; no. 17104 at the William and Lynda Steere Herbarium of the New York Botanical Garden [code, NY]); Callicostella pallida (Hornsch.) Ångstr. (Brazil, Soares; no. 544 at the Herbarium of the University of Brasília [code, UB]); Callicostella pallida (Hornsch.) Ångstr. (Surinam, Allen; no. 25421 at NY); Callicostellopsis meridensis (Müll. Hal.) Broth. (Venezuela, Griffin \& López; no. PV-89 at NY); Cyclodictyon albicans (Hedw.) Kuntze (Panama, Folsom; no. 4336 at NY); Cyclodictyon roridum (Hampe) Kuntze, (Ecuador, Croat; no. 49416 at NY); Hypnella pallescens (Hook.) A. Jaeger (Puerto Rico, Reese; no. 14544 at NY); H. pilifera (Hook. f. \& Wilson) A. Jaeger (Brazil, Vital \& Buck; no. 19997 at NY); H. diversifolia (Mitt.) A. Jaeger (Ecuador, Steere; no. 27673 at NY); H. diversifolia (Mitt.) A. Jaeger (Colombia, Churchill et al.; no. 18335 at the Herbarium of the Botanical Institute of São Paulo [code, SP]); H. diversifolia (Mitt.) A. Jaeger, (Costa Rica, Crosby; no. 5914 at SP); $H$. diversifolia (Mitt.) A. Jaeger (Colombia, Churchill et al.; no. 14981 at SP); Pilotrichidium antillarum Besch. (Guadeloupe, Duss; no. 1045 at NY); and P. callicostatum (Müll. Hal.) A. Jaeger (Colombia, Ramos et al.; no. 1447 at NY).

\section{Preparation of material}

For each plant, 15-20 lateral and dorsal leaves were taken from branches. As in the pleurocarps, the branches are always generating new leaves, so they were removed from the tip (younger leaves) all the way to the base (older leaves). Samples were prepared according to Bozzola \& Russel (1998) and Câmara \& Kellogg (2010), although with a more gradual dehydration series, in $5 \%$ increments, at the same time intervals, between $50 \%$ and $100 \%$ followed by two final steps at $100 \%$ and $100 \%$ in plants with thinner cell walls. Plants were submitted to critical point drying using a Denton DCP-1 dryer (Denton Vacuum LLC, Moorestown, NJ USA) and a Bal-Tec CPD 030 dryer (Bal-Tec AG, Balzers, Liechtenstein), with liquid $\mathrm{CO}_{2}$ as the transition fluid. After drying, leaves were mounted on stubs and sputter-coated with gold and gold-palladium layers using two sputter coaters: a Hummer 6.2 (Anatech, Union City, CA, USA) and a Bal-Tec SCD 050 (Bal-Tec AG). The sputter-coated specimens were kept in a dessicator containing silica gel before SEM visualization. The samples were observed and photomicrographs were taken with JSM-840 A SM and JSM-5410 LV scanning electron microscopes (JEOL, Tokyo, Japan) at $15 \mathrm{kV}$ and at a working distance of $10 \mathrm{~mm}$. All cell measurements were taken from mature dorsal and lateral leaves, and at least 10 measurements of papilla dimensions were made for each specimen. Twenty-five papillose cells for each individual were also measured under SEM (Tab. 1).

\section{Results and discussion}

In the Pilotrichaceae genera evaluated, papillae were found only on abaxial leaf surfaces. Basipetal papilla development along the leaf was observed in all species, with younger papillae at the leaf base and mature papillae in the apical region. In addition, the papillae remained prominent even when cells collapsed due to specimen preparation, suggesting that papillae in Pilotrichaceae are solid and created by thickening of cell walls. Pluripapillose taxa had cells that were five times longer than they were wide, whereas those of the unipapillose taxa were irregularly isodiametric (Tab. 1). Seven distinct kinds of mature papillae occur and can be referred to as cylindrical, denticulate, filiform, forked, rounded, semi-conical and stellate (Fig. 1-3). These types can be distinguished as follows:

Cylindrical papillae are simple (not branched) protuberances that are elongate and acute, $1.5-4 \mu \mathrm{m}$ in diameter at the base and 4-6 $\mu \mathrm{m}$ long. These papillae have "striae" that are vertical in relation to the papilla length and occur as

Table 1. Dimensions of cells with different types of papillae. The lengths and widths are averages of 25 measurements made under scanning electron microscopy in the same region of a mature leaf.

\begin{tabular}{lccc}
\hline Papilla type & Length, $\mu \mathrm{m}$ & Width, $\mu \mathrm{m}$ & Length:Width \\
\hline Cylindrical $^{*}$ & 23.9 & 10.5 & 2.3 \\
Forked & 45.5 & 5.0 & 9.1 \\
Filiform $^{*}$ & 25.5 & 5.0 & 5.1 \\
Rounded $^{*}$ & 7.0 & 7.0 & 1.0 \\
Semi-conical $^{*}$ & 13.3 & 13.3 & 1.0 \\
Denticulate & 14.9 & 6.7 & 2.2 \\
Stellate & 64.0 & 5.0 & 12.8 \\
\hline
\end{tabular}

*Unipapillose taxa. 
singletons at the geometric center of the cell (Fig. 1A). This type was observed in the majority of mature leaf cells on any given leaf. When young, they are small outgrowths, 1-2 $\mu \mathrm{m}$ in diameter at the base. This kind of papilla was observed only in Callicostellopsis meridensis (Fig. 1A and 1B).

Filiform papillae are simple (not branched), hair like projections that are 2- $\mu \mathrm{m}$ wide at the base and 4-6 $\mu \mathrm{m}$ long. These papillae have "striae" that are twisted in relation to the papilla length. Four to five such papillae typically occur on a single cell, and are distributed regularly along the axis of the cell. They are observed in the majority of mature cells on any given leaf. When young, this type is a small outgrowth, with the same diameter throughout but shorter than mature papilla. This kind of papilla was observed only in Hypnella pilifera (Fig. 1C and 1D).

Rounded papillae are simple (not branched), wart-like, with a rounded apex, $1 \mu \mathrm{m}$ wide at the base and $0.8 \mu \mathrm{m}$ tall. These papillae are smooth. Ten such papillae occur per cell and are irregularly distributed along the axis. Young papillae are wider but shorter than mature papillae. This kind of papilla was observed in Pilotrichidium antillarum and $P$. callicostatum. However, in the former, papillae were observed only on the apical cells, whereas in the latter, they were observed on all leaf cells (Fig. 1E and 1F).

Forked papillae are dichotomously branched, with stems that are 2-4 $\mu \mathrm{m}$ long and 1-3 $\mu \mathrm{m}$ in diameter, each supporting two equal branches. These papillae have "striae" that are vertical in relation to the papilla length, typically five per cell, regularly distributed along the cell axis of the

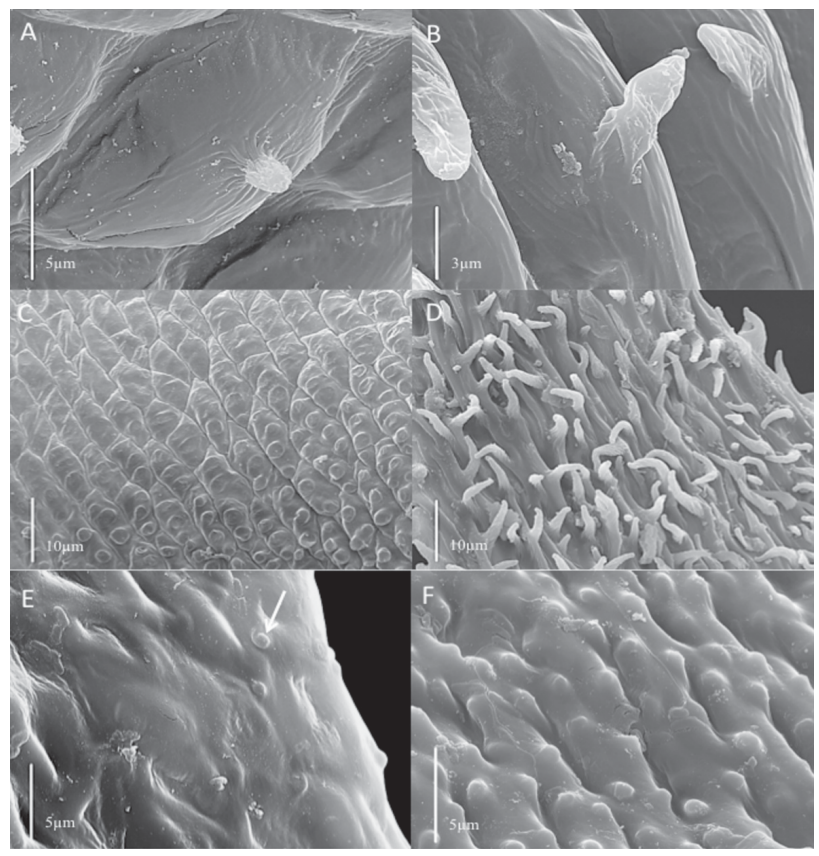

Figure 1. A-B. Cylindrical papilla in Callicostellopsis meridensis (Müll. Hal.) Broth. A. Immature papilla. B. Mature papilla. C-D. Filiform papilla in Hypnella pilifera (Hook. f. \& Wilson) A. Jaeger. C. Immature papilla. D. Mature papilla. E-F. Rounded papilla in Pilotrichidium Besch. E. Immature papilla. F. Mature papilla. majority of mature leaf cells on any given leaf. There are morphological changes during maturation; the papillae start out as simple, unbranched outgrowths (Fig. 2A) that branch during maturation. This kind of papilla was observed only in Hypnella diversifolia (Fig. 2A-C).

Stellate papillae are branched, with 3-5 branches diverging from the apex of the stem, which is $1-4 \mu \mathrm{m}$ wide at the base and 1.5-3.5 $\mu \mathrm{m}$ long. These papillae have "striae" that are vertical in relation to the papilla length. Three to five papillae are regularly distributed along the cell axis of the majority of mature cells in a leaf. These papillae also undergo morphological changes during their development; they start out as simple outgrowths that later grow 3-5 branches. This kind of papilla was observed only in Hypnella pallescens (Fig. 2D-F). Semi-conical papillae are simple (not branched), ca. 2.5 $\mu \mathrm{m}$ wide at the base and 2-3 $\mu \mathrm{m}$ long. These papillae have "striae" that are vertical in relation to the papilla length and occur on the majority of mature cells, always in the center of the cell. When young, they are small outgrowths, with the same diameter but shorter than mature papillae. This kind of papilla was observed only in Callicostella pallida (Fig. 3A-C). Denticulate papillae are simple (not branched) but with short acute protuberances, giving the cell a toothed appearance. The papilla are ca. $2.5 \mu \mathrm{m}$ wide at the base and long. These papillae have "striae" that are regular in relation to the papilla length. There are two per cell on the apical cells of the limbidium only, forming a denticulate margin. When young, they are as wide but shorter than mature papillae. This kind of papilla was observed in Callicostella colombica and C. pallida (Fig. 3D-F).

These papillae thus differ in shape and, based on their development, can be organized into two groups as described by Câmara \& Kellogg (2010). The majority of papillae (cylindrical, denticulate, filiform, rounded or semi-conical) do not undergo morphological changes during their maturation, except for changes in height (Fig. 1 and 3). The remaining papillae (forked and stellate) change not only in size but also in shape (Fig. 2), first emerging as simple protuberances, then presenting a growth pause, after which they branch and resume growth until reaching maturity. Under SEM, we found that two species of Cyclodictyon had no papillae at any developmental phase, as we had already seen under light microscopy.

Our finding that papillae were present only on the abaxial surface has also been reported for the Sematophyllaceae and Fissidentaceae (Belin et al. 1974; Câmara \& Kellogg 2010), although they have been reported to occur on both surfaces in the Pottiaceae (Mishler 1987). The fact that the papillae of Pilotrichaceae species remained prominent when the cells collapsed suggests that the Pilotrichaceae papillae are solid, justifying the use of the term "papillae" to refer to such outgrowths, unlike those observed in the Sematophyllaceae, which are actually mammillae (Câmara \& Kellogg 2010). Cross sections would be useful in helping define what these outgrowths really are. 


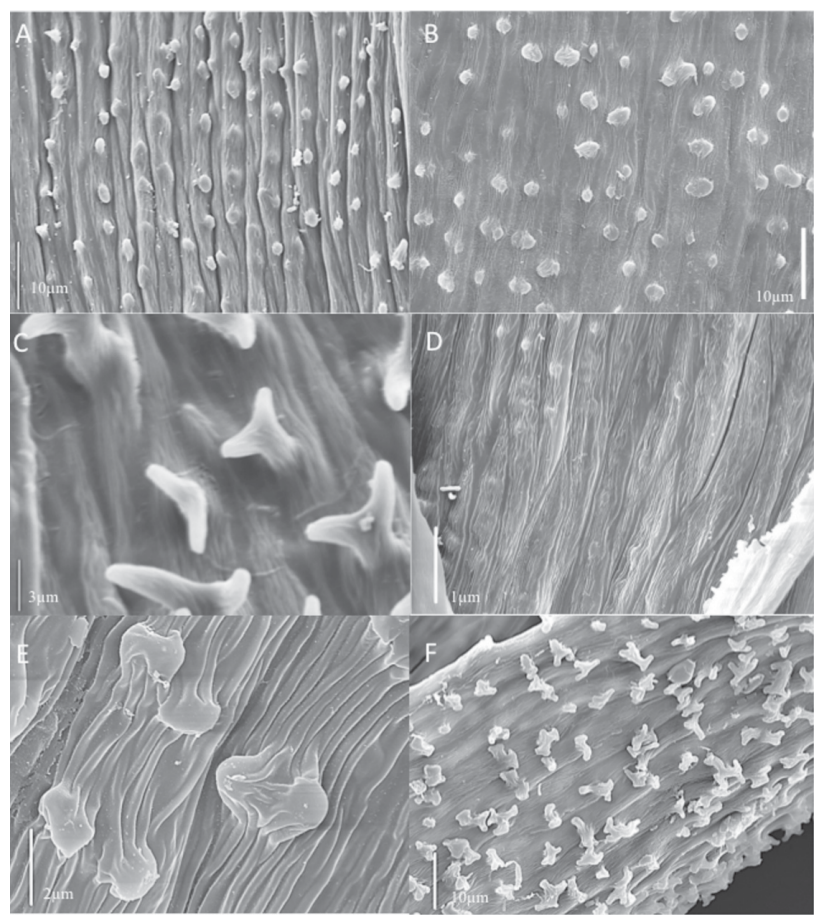

Figure 2. A-C. Forked papilla in Hypnella diversifolia (Mitt.) A. Jaeger. A. Immature papilla. B. Division phase. C. Mature papilla. D-F. Stellate papilla in Hypnella pallescens (Hook.) A. Jaeger. D. Immature papilla. E. Division phase. F. Mature papilla.

Forked and stellate papillae have the same initial phase, with the same pattern of division when they emerge on the cell. Although both are branched when mature, they differ in that the former has two regular branches and the latter has multiple irregular branches. This development pattern was also observed by Mishler (1987) in Syntrichia papillosissima (Copp.) Loeske, as well as in Tortula papillosissima (Copp.) Broth., which presents a mature morphology similar to that of the stellate papillae. The baggy papillae observed in Taxithelium planum (Brid.) Mitt. by Câmara and Kellogg (2010) have the same kind of division found in forked and stellate papilla but do not develop into branched papillae. The filiform papillae seen in Hypnella pilifera and the baggy papillae seen in Taxithelium nepalense (Schwägr.) Broth. (Câmara \& Kellogg 2010) show the same initial phase, emerging initially as a line from the cell lumen, occupying almost the entire cell width. However, in the mature form, they are distinct, the papillae being hair-like in the former and rounded in the latter.

According to Buck (1998), Callicostella colombica has a toothed margin and smooth cells. In the present study, the cells were indeed smooth under SEM, and the denticulate margin was formed by two papillae at the apex of apical and marginal cells (denticulate papillae), as shown in Fig. 3F. In order to help assess the phylogenetic significance of papilla types, we mapped them on the phylogenetic tree devised by Buck et al. (2005). The Pilotrichaceae are divided in ten clades (Fig. 4), informally designated Pilotrichum, Hypnella, Thamniopsis, Pilotrichidium, Callicostellopsis, Brymela, Le-

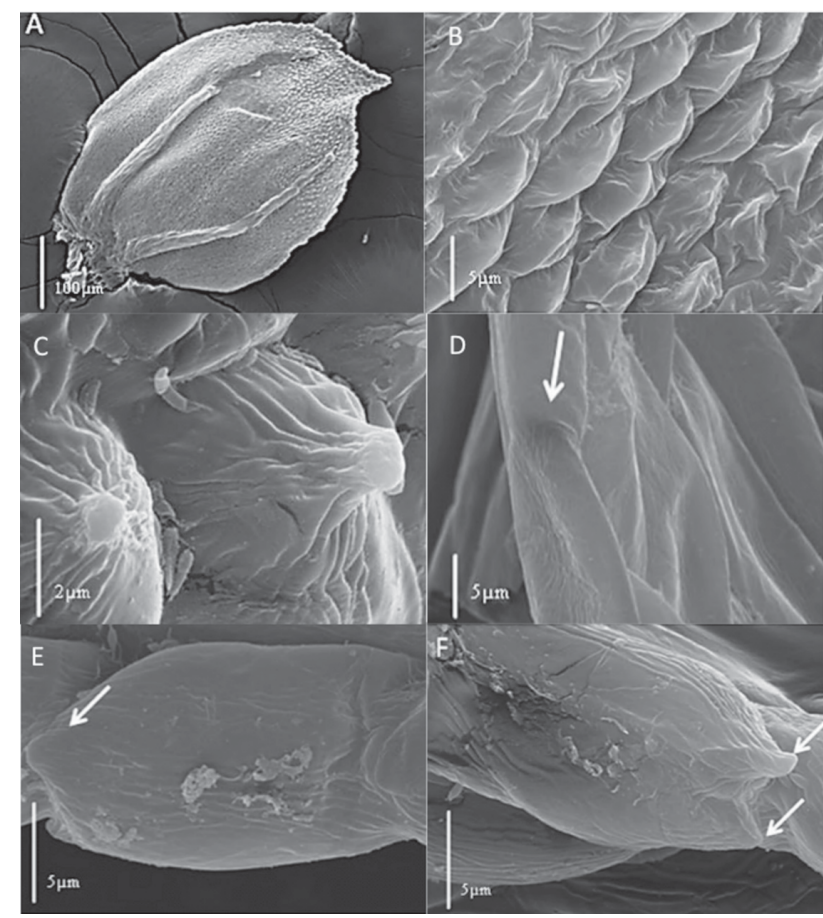

Figure 3. A-C. Semi-conical papilla in Callicostella pallida (Hornsch.) Ångstr. A. Young leaf with papilla only in apical cells. B. Young leaf without papilla. C. Mature papilla. D-F. Denticulate papilla in Callicostella (Müll. Hal.) Mitt. D. Young leaf without papilla (arrow). E. Immature papilla (arrow). F. Mature papilla (arrows).

pidopilum, Trachyxiphium, Callicostella and Cyclodictyon. The Pilotrichum, Thamniopsis, Brymela, Lepidopilum, Trachyxiphium and Cyclodictyon clades do not contain any papilla-bearing taxa.

The Hypnella clade (Fig. 4) is represented by one species, Hypnella pallescens, which differs from all other investigated taxa by its stellate papilla. Hypnella is traditionally recognized by its seriate papilla observed under light microscopy, as confirmed here by SEM. However, the genus is not monophyletic (Buck et al. 2005), and H. pallescens and H. diversifolia belong to two distinct clades (Fig. 4). The papillae in these species start out as simple protuberances but differ at maturity (becoming stellate and forked papillae, respectively), which suggests polyphyly of the genus. In addition, $H$. pilifera differed from the other two species in terms of papilla development and shape (filiform), suggesting that $H$. pilifera does not belong with the other two. Unfortunately, $H$. pilifera has yet to be sampled in phylogenetic studies.

The Pilotrichidium clade (Fig. 4) is composed of eight species: Brymela tutezona Crosby \& B.H. Allen; Trachyxiphium vagum (Mitt.) W.R. Buck; Hypnella diversifolia; Thamniopsis pendula (Hook.) M. Fleish.; Hemiragis aurea (Lam. ex Brid.) Kindb.; Thamniopsis cruegeriana (Müll. Hal.) W.R. Buck; Pilotrichidium antillarum; and P. callicostatum. Only three species exhibit papillae: $H$. diversifolia, $P$. antillarum and $P$. callicostatum. The species $P$. antillarum and $P$. callicostatum, which revealed the monophyly of the genus, have the same kind of papilla, differing only 


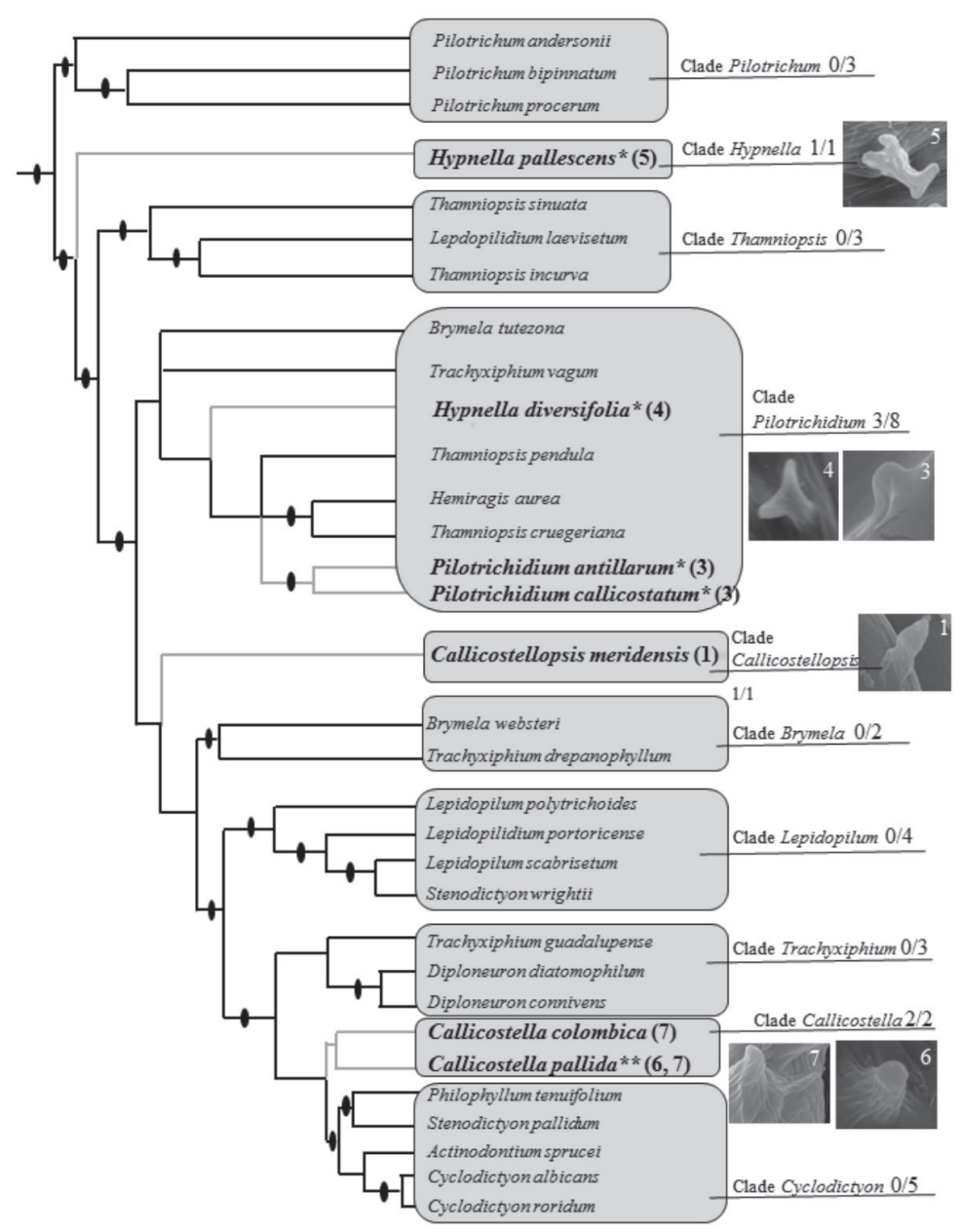

Figure 4. Phylogeny of the Pilotrichaceae based on Buck et al. (2005).

Gray lines and names in boldface identify papillose clades. Numbers in parentheses after taxa and in scanning electron micrographs indicate the kind of papilla described: 1 - cylindrical; 3 - rounded; 4 - forked; 5 - stellate; 6 - semi-conical; and 7 - denticulate. Gray rectangles refer to the division of phylogeny in informal clades. Numbers after clades names refer to the proportion of papillose taxa per number of taxa sampled. ŸBayesian posterior probabilities exceeding $95 \%$. ${ }^{\star}$ Pluripapillose taxa; ${ }^{* *}$ Taxa with dimorphic papillae.

in location (P. antillarum has papilla only in cells of the extreme apex and P. callicostatum has papillae over the entire surface of the leaf), representing a synapomorphy for the genus. However, although $H$. diversifolia also presents papillae, they are different in morphology and development from those of Pilotrichidium Besch., a trait suggestive of homoplasy.

The Callicostellopsis clade (Fig. 4) is composed only of Callicostellopsis meridensis. The genus is unispecific and has papillae that are distinct from those of all other taxa investigated. Callicostellopsis meridensis is the sister group to a clade comprising several genera with smooth cells (Fig. 4). The unique shape of the papillae suggests an autapomorphy.

The Callicostella clade (Fig. 4) contains only two species in the tree, as Buck et al. (2005) made a new combination, transferring C. diatomophila (Müll. Hal.) M. Fleisch. to Diploneuron E.B. Bartram. Only two of the 97 Callicostella species (C. colombica and C. pallida) were sampled from this clade, indicating the existence of at least a monophyletic core in the genus. This clade contains plants with denticulate papilla, which may be considered a synapomorphy for the genus. Callicostella pallida still exhibits one more kind of papilla (semi-conical papilla), similar to those of most species of the genus. However, Callicostella is a genus with a large number of species and it is necessary to increase the number of taxa sampled in order to clarify the evolutionary history of the group.

Within the monophyletic papillose genera sampled by Buck et al. (2005) -Callicostella and Pilotrichidium-the development and morphology of the papillae were similar, suggesting synapomorphies for the groups. In the polyphyletic genus Hypnella, the development and morphology of papillae was found to differ among species, indicating that the papillae in these species may have appeared indepen- 
dently throughout the evolution of the group, suggesting autapomorphies. In Callicostellopsis, the unique shape of the papillae also distinguished it from all other clades. Therefore, our study showed that the papillae may be informative of the evolutionary history of the papillose genera within the family Pilotrichaceae, suggesting the previous use of what now appear to be non-informative features to delimit taxa, may help explain the large polyphyletic nature of the taxa shown by Buck et al. (2005).

\section{Acknowledgments}

This study received financial support from the Brazilian Coordenação de Aperfeiçoamento de Pessoal de Nivel Superior (CAPES, Office for the Advancement of Higher Education). We are grateful to the staff of the Electron Microscopy Lab at the University of Brasília, for the use of the SEM; to the herbaria of the New York Botanical Garden and the Botanical Institute of São Paulo, for the specimens provided; to William R. Buck, for his assistance and text revision; and to Marcela Thadeo, Alejandra Vasco and Carolina Schäffer, for their assistance.

\section{References}

Belin, J.M., Bizot, M. \& Dury, M.N. 1974. Le tissue foliaire chez les Fissidens. Société Botanique de France, Colloque Bryologie 121: 111-116.

Bozzola, J.J. \& Russel, L.D. 1998. Electron Microscopy. Principles and Techniques for Biologists. 2nd ed. Sudbury, Jones \& Bartlett.

Brotherus, V.F. 1925. Musci (Laubmoose). 2. Hälfte. In A. Engler (Ed.). Die natürlichen Pflanzenfamilien. 2. ed. Leipzig, W. Engelmann.

Buck, W.R. 1998. Pleurocarpous mosses of the West Indies. Memoirs of The New York Botanical Garden 82: 1-400.

Buck, W.R. 2007. The history of pleurocarpous classification: two steps forward, one step back. The Systematics Association Special Volume 71: 1-18.

Buck, W.R. \& Goffinet, B. 2000. Morphology and classification of mosses. Pp. 71-123. In: Shaw, A.J. \& Goffinet, B. (Eds.). Bryophyte Biology. Cambridge, Cambridge University Press.
Buck, W.R.; Cox, C.J.; Shaw, J. \& Goffinet, B. 2005. Ordinal relationships of pleurocarpous mosses, with special emphasis on the Hookeriales. Sistematics and Biodiversity 2: 121-145.

Câmara, P.E.A.S. \& Kellogg, E.A. 2010. Morphology and development of leaf papillae in Sematophyllaceae. The Bryologist 113: 22-33.

Câmara, P.E.A.S. \& Buck, W.R. 2012. A re-interpretation of the Fabroniaceae, a phylogenetic perspective. The Bryologist 115: 109-117.

Cano, M.J. 1994. Importancia de la microscopia electrónica en los estudios taxonómicos de briofitos. Boletin de La Sociedad Española de Briología 4: 1-3.

Crosby, M.R. 1974. Toward a revised classification of the Hookeriaceae (Musci). Journal of the Hattori Botanical Laboratory 38: 129-141.

Crosby, M.R.; Magill, R.E.; Allen, B. \& He, S. 2000. A Checklist of the Mosses. St. Louis, Missouri Botanical Garden.

Crum, H. 1984. Notes on tropical American mosses. The Bryologist 87: 203-216.

Gardiner, A.; Ignatov, M.; Huttunen, S. \& Troitsky, A. 2005. On resurrection of the families Pseudoleskeacae Schimp. and Pylaisiaceae Schimp. (Musci, Hypnales). Taxon 54: 651-663.

Goffinet, B.; Buck, W.R .\& Shaw, A.J. 2009. Morphology, anatomy and classification of the Bryophyta. Pp. 55-138. In B. Goffinet \& A. J. Shaw (Eds.), Bryophyte Biology. 2nd edition. Cambridge, Cambridge University.

Gradstein, S.R.; Churchill, S.P. \& Salazar-Allen, N. 2001. Pilotrichaceae. In Guide to the bryophytes of tropical America. Memoirs of The New York Botanical Garden 86: 438-456.

Hedenäs, L. 1996. A cladistic overview of the "Hookeriales." Lindbergia 21: $107-138$

Hedenäs, L. 2007. Morphological characters and their use in pleurocarpous moss systematics. The Systematics Association Special Volume 71: 227-245.

Ireland, R.R. 1991. Cuticular papillae of Atrichum crispum. The Bryologist 94: 73-76.

Magill, R.E. 1990. Glossarium polyglottum bryologiae. Monographs in Systematic Botany from the Missouri Botanical Garden 33: 1-50.

Mishler, B.D. 1987. Leaf development in Tortula papillosissima (Pottiaceae). Memoirs of The New York Botanical Garden 45: 48-54.

Robinson, H. 1971. Scanning electron microscope studies on moss leaves and peristomes. The Bryologist 74: 473-483.

Vaz-Imbassahy, T.F.; Imbassahy, C.A.A. \& Costa, D.P. 2008.Sinopse de Pilotrichaceae (Bryophyta) no Brasil. Rodriguésia 59: 765-797.

Werner, O.; Ros, R.M. \& González-Mancebo, J.M. 2003. The variability of papillae on the laminal cells of Barbula indica (Hook.) Spreng. (Pottiaceae: Musci): a morphological and molecular approach. Cryptogamie, Bryologie 24: 367-375. 